\title{
Staphylococcus aureus related mammary infection in cows: Correlation between somatic cell count and proteolysis during early and chronic phase of infection
}

\author{
I. Michelutti, K. Haddadi and Y. Le Roux ${ }^{1}$ \\ Unité de Recherche "Animal et Fonctionnalités des Produits Animaux", \\ Institut National de la Recherche Agronomique, France \\ ENSAIA (Ecole Nationale Supérieure d'Agronomie et des Industries Alimentaires) \\ 2 Avenue de la Forêt de Haye B.P. 172, 54505 Vandoeuvre Cedex, France
}

\begin{abstract}
Experimental mastitis induced by the $S$. aureus in six dairy cows was performed to investigate the relationship between somatic cell count (SCC) and proteolysis during early and chronic phase of infection (up to 28 days post-infection). An elevated level of infection was detected during the early phase and was characterized by a measurable link between SCC and proteose-peptone content. In contrast to this observation, no significant relationship was detectable between the two parameters during the chronic phase of infection. During this phase the measurement of SCC could not be established as a reliable indicator of milk proteolysis. Moreover, the results of this study demonstrated that the high risk of milk proteolysis associated with an elevated SCC content does not consistently obey the opinion that excessive SCC results in a high level of proteolysis of milk. Our results were compared with experimental $E$. coli mastitis in order to evaluate the differences that exist between the courses of bovine intramammary infection caused by $S$. aureus and E. coli.
\end{abstract}

\section{INTRODUCTION}

Somatic cell count (SCC) is routinely used to asses and monitor the healthrelated condition of the udder and is commonly used as a reliable indicator of subclinical incidence of mastitis. This category of mastitis has potentially detrimental economic consequences for dairy farmers leading to increases in cow culling and loss in dairy production (Nielen et al., 1995) affecting dairy companies by

\footnotetext{
${ }^{1}$ Corresponding author: e-mail: yves.leroux@ensaia.inpl-nancy.fr
} 
decreasing the availability of cheese (Miranda and Grippon, 1986), bitterness in processed dairy products such as cheese, ultra-heat-treated (UHT) and pasteurized milk (Harwalkar et al., 1993), and reducing the shelf-life of these dairy products. The origin of these degradations are proteases released from somatic cells (predominantly leukocyte blood cells) and from the plasmin-plasminogen system (Le Roux et al., 1995; Kelly et al., 2006). The composition of somatic cells obtained from the milk of healthy cows embody macrophages, polymorphonuclear (PMN) leucocytes and lymphocytes in proportions approximating to 60,12 and $28 \%$, respectively. During early inflammation, the content of PMN increase to levels above $90 \%$, however the SCC content is variable depending on the nature of cow and the pathogenic strains (Rainard and Riollet, 2003).

Milk proteolysis can be evaluated by monitoring two major parameters. The first parameter relates to proteose-peptone content (PPC) which is a heat stable and an acid soluble protein fraction of milk. PPC is a suitable parameter for measurement of proteolysis, including proteolysis which is attributed to plasmin and non-plasmin activity in quarter-milk obtained from cow with sub-clinical or clinical mastitis (Le Roux et al., 1995; Moussaoui et al., 2004). This fraction can be categorized into two groups: the first comprises of a complex protein hydrolysate casein mixture resulting mainly from proteolysis of the $\beta$-caseins located in the lower $\alpha_{\mathrm{s} 2}$-and $\alpha_{\mathrm{s} 1}$-casein and $\kappa$-casein regions (Moussaoui et al., 2004). The second group includes a PP3 component which is not a product of endogenous proteolysis. The second parameter corresponds to the proportion of insoluble peptide that exists at $\mathrm{pH} 4.6$ corresponding to the majority of $\gamma$-casein originating from plasmin activity.

Number of studies investigating possible links between bacteria and milk composition: The impact of $E$. coli on milk composition was well studied (Moussaoui et al., 2004; Haddadi et al., 2006) and proteases and protein degradation in milk from cows infected with Streptococcus uberis was investigated recently (Larsen et al., 2004). S. aureus is a pathogen causing subclinical mastitis that contains numerous extracellular proteases (Shaw et al., 2005). Previous studies examined the relationship between SCC and composition of milk in naturallyoccuring udder infected with $S$. aureus (Coulon et al., 2002; Leitner et al., 2006). However, to the best of our knowledge, no such study investigating the inflammatory response in an experimental mastitis model in the early phase of infection has been documented in this area of research.

The aim of this study was to evaluate in the experimental $S$. aureus mastitis model, the relationship between somatic cell count and proteolysis during early and chronic phases of inflammatory response in comparison with E. coli. 


\section{MATERIAL AND METHODS}

\section{Animal and inoculation procedure}

All data were collected at the "La Bouzule" search farm of the Department of Animal Sciences of ENSAIA. Six Prim'holstein in mid lactation, in which SCC of each quarter does not exceeded 50000 cells $/ \mathrm{mL}$ and free of major pathogens, were selected for study. The cows were inoculated with $S$. aureus 107.59 serotype 53 (from Laboratory of Infectious Pathology and Immunology, INRA, Tours). Subclinical mastitis was principally induced by this bacteria as the major infection. One quarter (back-right) in each cow was inoculated intracisternally at the end of milking with $150 \mathrm{cfu} / \mathrm{mL}(0.2 \mathrm{~mL}$ of pyrogen free saline with $150 \mathrm{cfu})$. The teat end was cleaned and disinfected with alcohol before inoculation. The back leftquarter served as a control population.

\section{Milk sample and analysis}

Quarter milk was sampled before experimental infection and 21 samples for each cow and each quarter were realized during the 28 days of experiment. Fourteen samples obtained by milking in the morning and evening during the early phase of infection corresponded to Post-Infection (PI) ( 0 to 7 days) and 7 samples obtained by morning milking during the chronic phase of infection coresponded to 7 to 28 days PI.

The following parameters were determined for each milk sample: SCC (Fossomatic 215 cell counter, Foss Electric, Hillerød, Denmark) and $\mathrm{pH}(\mathrm{pH}-$ meter/ionometer, Orion, 920A, Boston, MA).

Total $\mathrm{N}$ content (TN), NPN after precipitating proteins with TCA $(12 \%$ of the final solution) and the soluble $\mathrm{N}$ content ( $\mathrm{SN}$ ) after precipitating casein were determined using the Kjeldahl method by calibrating the $\mathrm{pH}$ meter to 4.6 (automatic titration on a Vapodest 6; Gerhardt, Bonn, Germany). The percentage of insoluble peptide at $\mathrm{pH} 4.6$ was determined by fast protein liquid chromatography analysis (Pharmacia, Uppsala, Sweden) on a Mono Q HR 5/5 anion-exchange column (Collin et al., 1991).

The proteose-peptone fraction was extracted in accord with the fractionating scheme recommended by Andrews et al. (1983): the supernatant S1 obtained after centrifugation $(6000 \mathrm{~g}$ for $15 \mathrm{~min})$ of a pre-heated $\left(95^{\circ} \mathrm{C}\right.$ for $\left.30 \mathrm{~min}\right)$ and an acid treated $(\mathrm{pH}=4.6 ; 1 \mathrm{M}$ acetic acid) milk sample, was precipitated with TCA (final concentration of $12 \%)$. Following centrifugation of S1 (6000 $\mathrm{g}$ for $15 \mathrm{~min})$, the resulting supernatant S2 was washed several times with an ethanol-ether mixture ( $\mathrm{vol} / \mathrm{vol}$ ) and subsequently frozen at $20^{\circ} \mathrm{C}$. The content of the proteose-peptone (PPC) was determined by calculating the difference between the $\mathrm{N}$ content of supernatant S2 from that of S1 using the Kjeldahl method (Vapodest 6 automatic titrator) and each sample was analysed in duplicate. 


\section{Bacteriological procedure}

Duplicate samples were taken aseptically according to Harmon (1990) and was spread over trypcase-soya containing sheep red blood cells.

\section{Statistical analysis}

In order to define precisely the relationship between the different parameters, Pearsons correlation statistical analysis was applied to two study events: correlation of day 0 to day $6.5(\mathrm{n}=14$ for each cow, corresponding to the early phase of infection) and correlation between day 7 to the day $27(n=7$ for each cow, corresponding to the chronic phase of infection). The normal distribution of the measures was checked.

\section{RESULTS}

Due to considerable variation amongst the cow population, individual curves are presented for each parameter.

\section{Evolution of somatic cell count (SCC) and bacterial counting}

Despite the broad variability amongst the cow population, similar changes in inflammatory responses to experimental infection was observed for all six cows.

No clinical signs of mastitis was noted for any of the study animals during the 28 day experimental period.

Prior to the experiment, SCC average was estimated as $20000 \mathrm{cells} / \mathrm{mL}$ (min 7 000; max 23000 cells $/ \mathrm{mL}$ ). The increase in SCC commenced after a period of 1 day, PI for $3 / 6$ cows, 2 days PI for $2 / 6$ and after 4 days PI for $1 / 6$ cows. For $5 / 6$ cows, the SCC peaked in the first week of the experiment. The peak of SCC exceeded $10^{6}$ cells $/ \mathrm{mL}$ for all cows but did not advance beyond $3.10^{6}$ cells $/ \mathrm{mL}$ (Figure 1).

The evolution of colony forming unit (CFU) was variable between cows. All counts exceeded $10^{4}$ bacteria/mL after 3 days PI (Figure 2) with the exception of one value that measured over $400 \cdot 10^{3}$ bacteria $/ \mathrm{mL}$. All measurements varied between $10^{4}$ and $2.10^{5}$ bacteria $/ \mathrm{mL}$ throughout the duration of the experiment. 


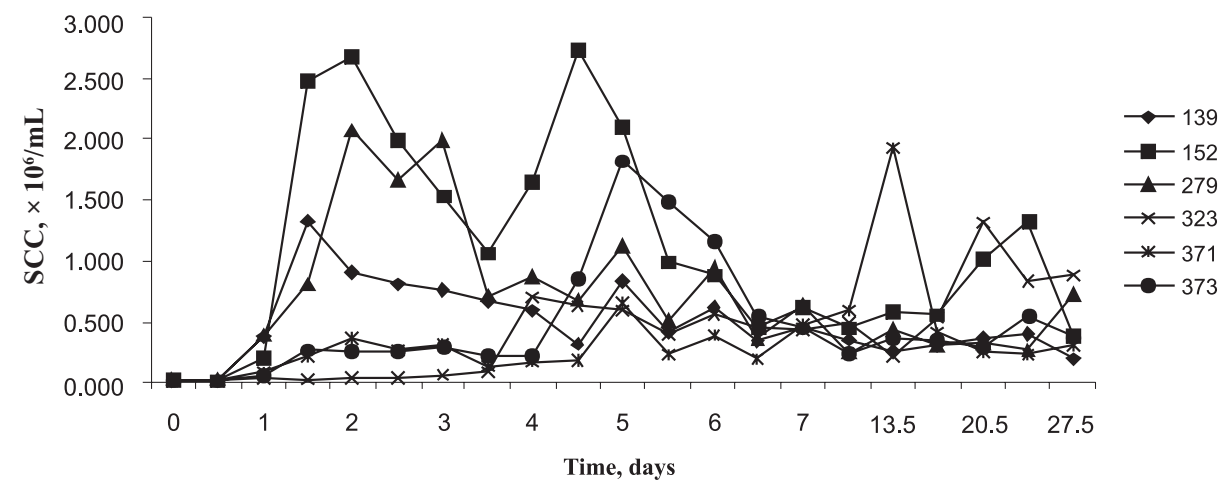

Figure 1. Variation of SCC in quarter milk after infusion of S. aureus (individual curves)

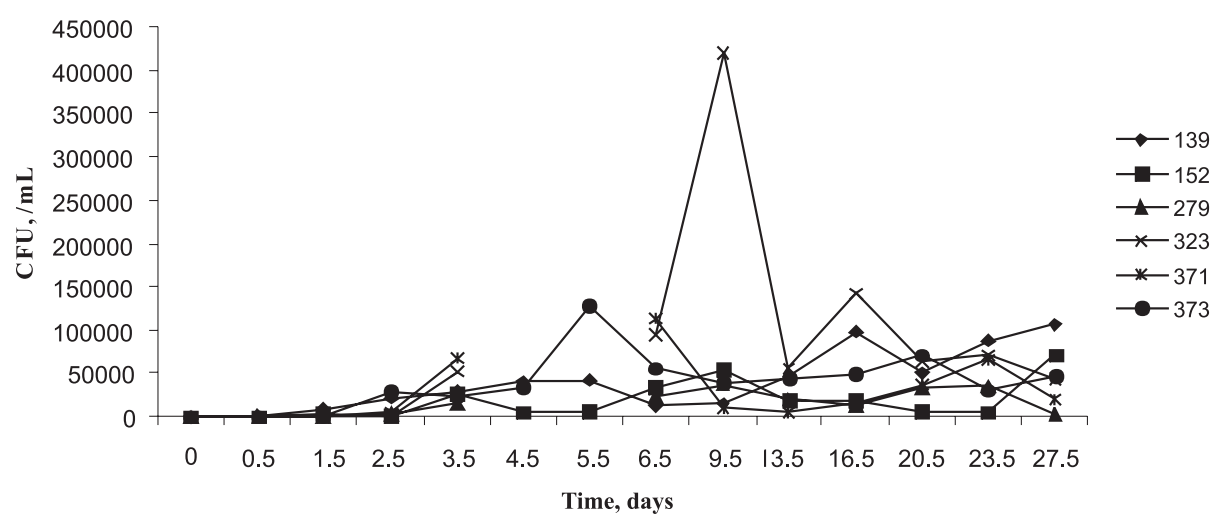

Figure 2. Variation of CFU in quarter milk after infusion of $S$. aureus (individual curves)

\section{Evolution of proteose-peptone content and pH 4.6 insoluble peptide}

Prior to the experiment, PPC values were between 0.72 to $1.22 \mathrm{~g} / \mathrm{L}$ (Figure $3 \mathrm{~A})$. The increase of PPC surpassed after one day PI for $2 / 6$ cows, 2 days PI for $2 / 6$ and 4 days PI for $2 / 6$ cows. For all cows, the peak of PPC reached 150 to $200 \%$ relative to the initial values.

Prior to the experiment, insoluble peptide values corresponding to the $\mathrm{pH} 4.6$ fraction were between 3.9 to $8.6 \%$ of the total casein (Figure 3B). The increase of $\mathrm{pH} 4.6$ insoluble peptide occurred regularly during the entire period of the 

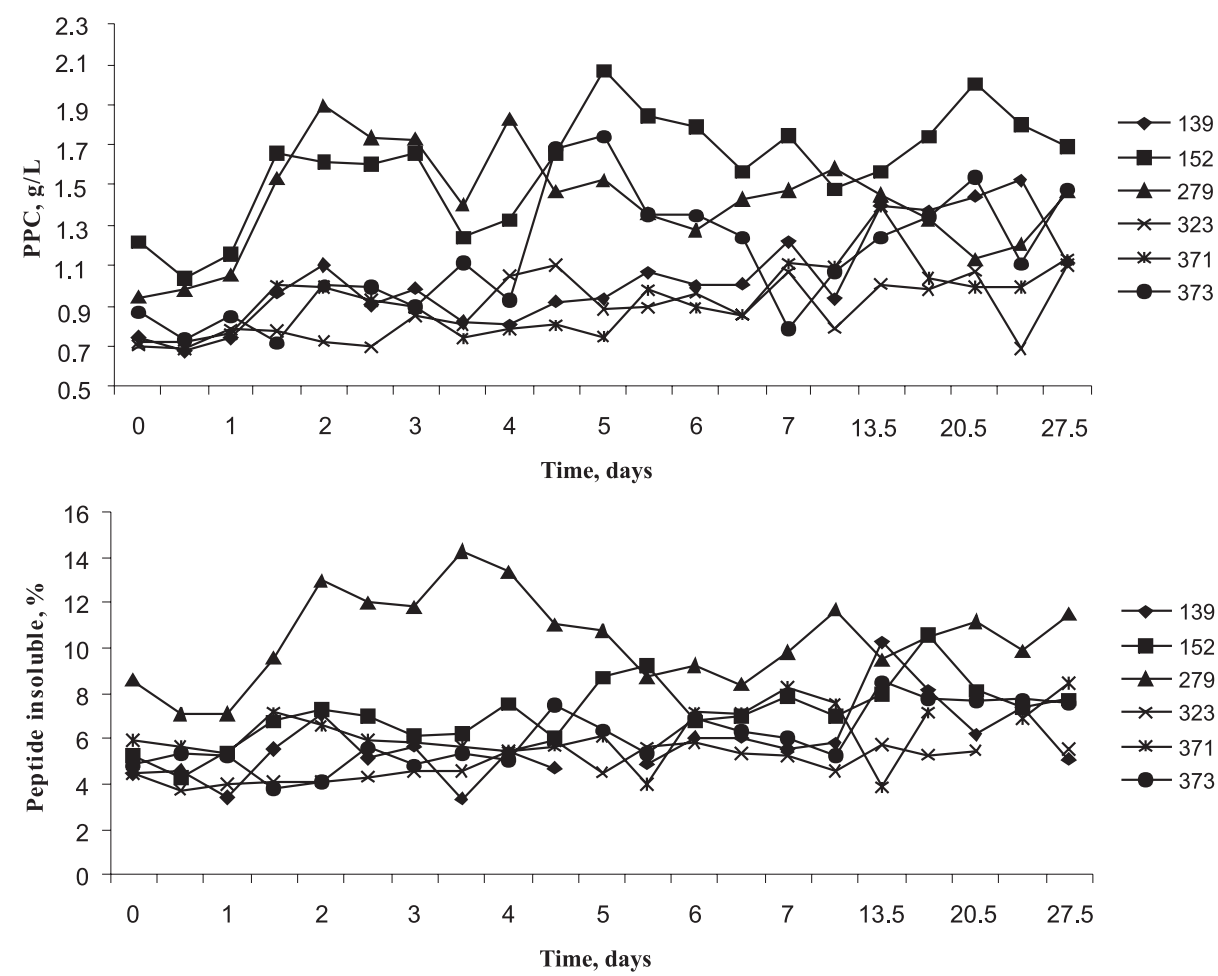

Figure 3. Variation of proteose-peptone content (A), insoluble peptide at $\mathrm{pH} 4.6$ (B) in quarter milk after infusion of $S$. aureus (individual curves)

experiment and exceeded $150 \%$ relative to the initial value with the exception of one cow (279) which presented an important increase between days 1 to 5 of the experiment accompanied by a value of $14 \%$ of the $\mathrm{pH} 4.6$ insoluble peptide.

\section{DISCUSSION}

\section{Evolution of CFU and SCC}

Intramammary infection with $S$. aureus elicited systemic signs and the response included marked reduction in milk output (data not shown). Increase in milk SCC were observed at $24 \mathrm{~h}$ PI during which, SCC of the 6 cows exceeded $10^{6}$ cells $/ \mathrm{mL}$ singly during the experiment but the SCC did not exceed $3.10^{6}$ cells $/ \mathrm{mL}$ irrespective of the cow tested. Such an evolution is typically related to subclinical infection where SCC remains low (for the majority $<10^{6}$ cells $/ \mathrm{mL}$ ) during the duration of the experiment. Coulon et al. (2002) have reported obtaining the same value in naturally occurring 
subclinical infection with $S$. aureus. A comparison of our results to previous studies using E. coli for experimental mastitis, revealed that for E. coli model, SCC in milk increased after a $3 \mathrm{~h}$ post-inoculation period with an average production of $10^{7}$ cells/ $\mathrm{mL}$ (Moussaoui et al., 2004). It is well known that $S$. aureus and E. coli implicate two inflammatory responses which have different outcomes: the inflammatory reaction, with a massive influx of neutrophils, allows the eradication of E. coli and a bacteriological cure, whereas in $S$. aureus infection bacteria are persistent in the udder and a chronic infection develops. Despite these differences in the inflammatory response, both $S$. aureus and E. coli infections present an acute phase. Even if the delay to elicit the recruitment of neutrophils to the mammary gland differs from E. coli and S. aureus infection, partly due to the absence of some critical cytokine in $S$. aureus infection, neutrophils constitute more than $75 \%$ of milk somatic cells in infected quarters during the acute stage of mastitis in these two models (Riollet et al., 2000).

Bacterial counting is also typical of subclinical mastitis (Figure 4). After $24 \mathrm{~h}$ of infection, a high concentration of PMN coincides with a low concentration of bacteria and bacteria multiply in milk triggering an amplification of inflammation which results in augmented recruitment of PMN (Rainard and Riollet, 2003). These results suggests that PMN controls the multiplication of bacteria in milk below $4.10^{5}$ bacteria $/ \mathrm{mL}$. If the level of contamination is very low to induce significant proteolysis, some strains of $S$. aureus are known to produce extracellular proteases. Karlsson and Arvidson (2002) have shown that among 92 S. aureus strains from infected human tissues, 21 strains produce zones of proteolysis on casein agar. In vitro studies have shown that staphylococcal proteases can cleave and degrade a number of important proteins (elastin, immunoglobulin). Thus, the major extracellular proteases secreted by $S$. aureus consist of a metalloproteinases, (aureolysin) staphylococcal serine proteases, cysteine proteases ( $\mathrm{SspB}$ ) and staphopains (Shaw et al., 2004). It seems necessary to explore the secretion of specific

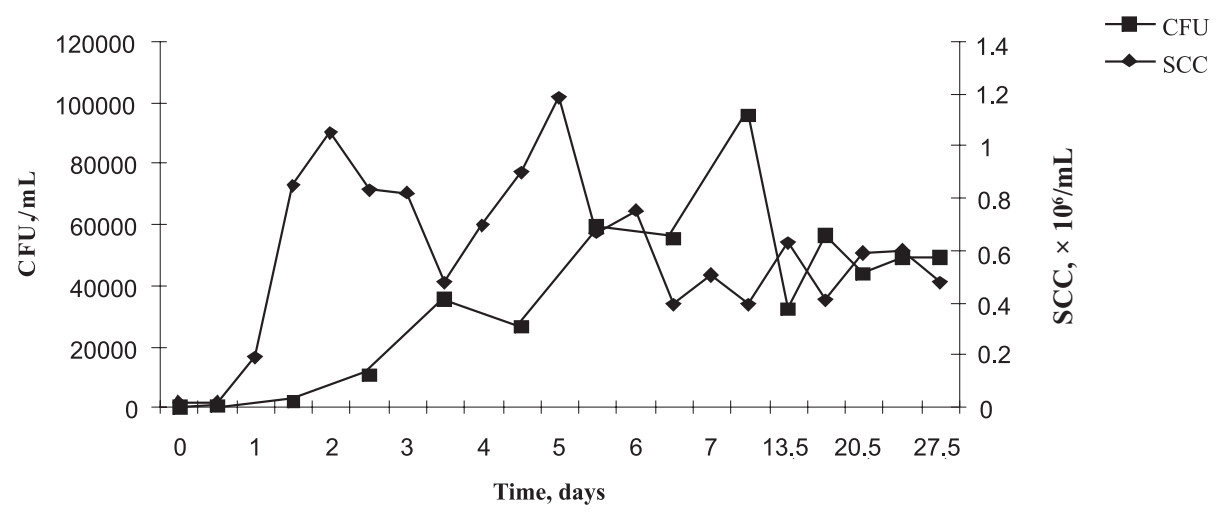

Figure 4. Relationship between SCC and colony forming unit in quarter milk after infusion of $S$. aureus (average curves) 
proteases by $S$. aureus during subclinical mastitis and to our knowledge no result has been published in this area.

\section{Evolution of PPC and $p H 4.6$ insoluble peptide}

Before the infusion of $S$. aureus, the average PPC for the 6 cows was $0.87 \mathrm{~g} / \mathrm{L}$. This basal level argues for a low level of proteolysis, even if for one cow (number 152), the initial level of PPC exceeds $1.2 \mathrm{~g} / \mathrm{L}$. If the intensity of the response is variable for the six cows, an increase of PPC during the experiment is observed for each animal and the peak of PPC reaches $2 \mathrm{~g} / \mathrm{L}$. This value shows that the intensity of proteolysis in subclinical mastitis model is very significant even if this level of proteolysis is weaker in comparison with other studies. Indeed, in the clinical mastitis model, with infusion of lipopolysaccharide of $E$. coli (LPS), the PPC can reach 3 to $4 \mathrm{~g} / \mathrm{L}$ (Moussaoui et al., 2003). Le Roux et al. (1995) have shown that, in naturally occuring subclinical mastitis (without characterization of the germ implicated in the infection), $\mathrm{PPC}$ can reach $3.6 \mathrm{~g} / \mathrm{L}$. These results show that if proteolysis is higher in clinical mastitis compared to sub-clinical mastitis (a fact that is well established), it demonstrates that there are a lot of variations between sub-clinical mastitis which depend on the type of bacteria, time of sampling after infection and individual responses.

In our experiment the plasmin activity has been not measured. Nevertheless, if the plasmin activity could reliably explain in part the variation of proteolysis, a significant measure of the proteolysis is attributed to the variation of SCC. This hypothesis was proposed more than 2 decades ago by De Rham and Andrews (1982) and confirmed recently by Moussaoui et al. (2004).

\section{Relationship between PPC and SCC}

For the six cows, for the early phase of infection (period from 0 to 7 days after infection) a good relation between SCC and PPC is observed. After that, during the chronic phase of infection (period from 7 to 27 days after infection), for $4 / 6$ cows, a disconnection between SCC and PPC is noted (Figure 5). The measure of the correlation confirms this description and show that correlation between SCC and PPC were significant for the early phase of infection $(\mathrm{r}=0.75)$ and for the chronic phase of infection (period from 7 to 27 days after infection) no significant correlation was measured (the log transformation of SCC does not change these results). Also, the maximum values observed for PPC for the six cows under investigation were very variable (1.15 to $2.10 \mathrm{~g} / \mathrm{L})$. These variations demonstrate that the endogenous proteolysis is significant and correlated with SCC during the first seven days of post infection. The primary response of the infection leads to an increase of SCC and endogenous proteolysis after which these two phenomenona show no correlation. 

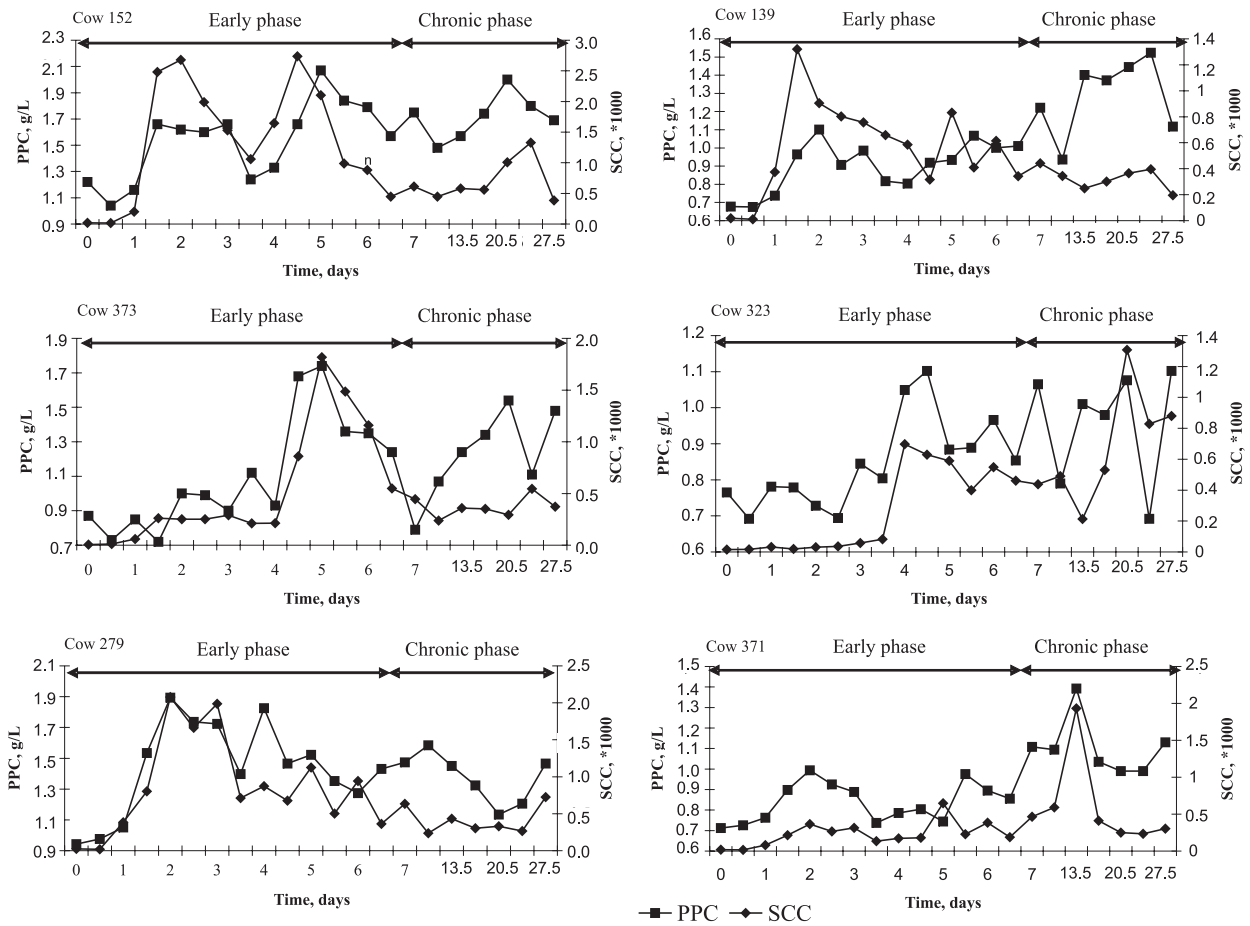

Figure 5. Relationship between proteose-peptone content and somatic cell count in quarter milk after infusion of $S$. aureus (individual curves)

The same results have been shown in clinical mastitis for the LPS model during the early phase of infection (Table 1), in this work the coefficient of correlation between SCC and PPC reaches 0.70 and the quantity of PMN exceeds $80 \%$ of the total of somatic cell during the maximal PPC response. In a separate investigation, Le Roux et al. (1995) showed that the correlation between SCC and PPC in naturally occurring subclinical mastitis approximates to 0.59 , this correlation is similar to that observed for the entire period of our experimentation (Table 1).

Table 1. Maximum values and correlation matrix between SCC and PPC in relation to different models of mastitis

\begin{tabular}{|c|c|c|c|c|c|c|c|}
\hline References & Model & $\begin{array}{l}\text { Type of } \\
\text { mastitis }\end{array}$ & $\begin{array}{l}\text { Phase of } \\
\text { infection }\end{array}$ & $\begin{array}{l}\mathrm{SCC} \\
/ \mathrm{mL}\end{array}$ & $\begin{array}{c}\text { PPC } \\
\mathrm{g} / \mathrm{L}\end{array}$ & $\begin{array}{c}r \\
\mathrm{PPC} / \mathrm{SCC}\end{array}$ & $\begin{array}{l}\text { Period of } \\
\text { infection }\end{array}$ \\
\hline \multirow[t]{3}{*}{ Our work } & S. aureus & sub-clinical & early & $2.710^{6}$ & 2.1 & 0.75 & 0-7 days \\
\hline & & & chronic & $1.510^{6}$ & 2.0 & 0.20 & 9-28 days \\
\hline & & & & - & - & 0.60 & $0-28$ days \\
\hline $\begin{array}{l}\text { Le Roux et } \\
\text { al. (1995) }\end{array}$ & $\begin{array}{l}\text { naturally- } \\
\text { occuring }\end{array}$ & sub-clinical & unknown & $3.510^{6}$ & 3.64 & 0.59 & unknown \\
\hline $\begin{array}{l}\text { Moussaoui } \\
\text { et al. (2002) }\end{array}$ & LPS & clinical & early & $3.510^{6}$ & 3.5 & 0.70 & $0-3$ days \\
\hline
\end{tabular}

$\mathrm{r}$ - coefficient of correlation 
Low cell recruitment during $S$. aureus infection appears to be the consequence of a lack of production of some chemoattractant or inflammatory mediators (Riollet et al., 2000; Bannerman et al., 2006). However, cell influx does exist after $S$. aureus intrammamary infusion. These observations presented neutrophil recruitment and a systemic inflammatory reaction even in the absence of some critical cytokines (Il-8, TNF $\alpha$ ) in the infected udder. Recently, Bannerman et al. (2006) showed that $S$. aureus elicits host production of TGF- $\alpha, \beta 1$ and $\beta 2$ in mediating mammary gland host innate immunes responses. Thus, for E. coli or $S$. aureus, the early phase of infection corresponded to acute inflammatory responses, where neutrophil migration was observed. This phase corresponded to a non-specific immunity response during which neutrophils form the first line of immunological defence in the bovine mammary gland against Gram-positive and Gram-negative pathogens. During this phase, the correlation between SCC and PPC is high for both LPS or $S$. aureus experimental mastitis even if the level of proteolysis and SCC is higher in LPS model. In the case of $S$. aureus, during the chronic phase of infection, which was accompanied by a specific immunity response, a dramatic decrease of the correlation between PPC and SCC is observed. It is well known that during the early phase, a large numbers of neutrophils comprising about $80-90 \%$ of the blood composition into the milk is observed and if the infective agent remains, other mononuclear cells are involved (T lymphocytes and monocytes) with neutrophils below $70 \%$ of the cell population in chronic mastitis (Rainard and Riollet, 2003). Moreover, recently, during the chronic phase of the infection, Grönlund et al. (2006) have shown that a number of differences in milk lymphocyte subsets exist between the early phase of infection and chronic sub-clinical phases of $S$. aureus mastitis.

The cytokine deficit in milk after $S$. aureus inoculation could have an impact on polymorphonuclear proteolysis in the mammary gland. Indeed, Bannerman et al. $(2004,2006)$ have shown that E. coli and $S$. aureus elicit differential innate immune responses following intramammary infection and cytokine IL-8 and (TNF- $\alpha$ ) is only observed in quarter infected with $E$. coli. It is well known that PMN proteolytic activities are regulated by some of these mediators of inflammation. Pro-inflammatory cytokines promote the activity of proteases at the transcriptionnal level, which is the case of IL-1 and IL-8 for collagenase IV (Opdenaker et al., 2001), IL-6, IL-2 and tumor necrosis alpha factor (TNF- $\alpha$ ) and for serine proteases such as elastase and cathepsin (Banks et al., 2001). Thus, the intensity of the inflammatory signal and its nature may influence the degree of activation of the cells recruited, the activation of the cells (especially PMN) could have an impact on the protease secretion in milk.

Thus, to explain the mechanism of proteolysis in milk during subclinical mastitis, it is necessary to identify the type of germ implicated and the date of infection, notably for subclinical mastitis. The type of germ impact, the cytokines which are 

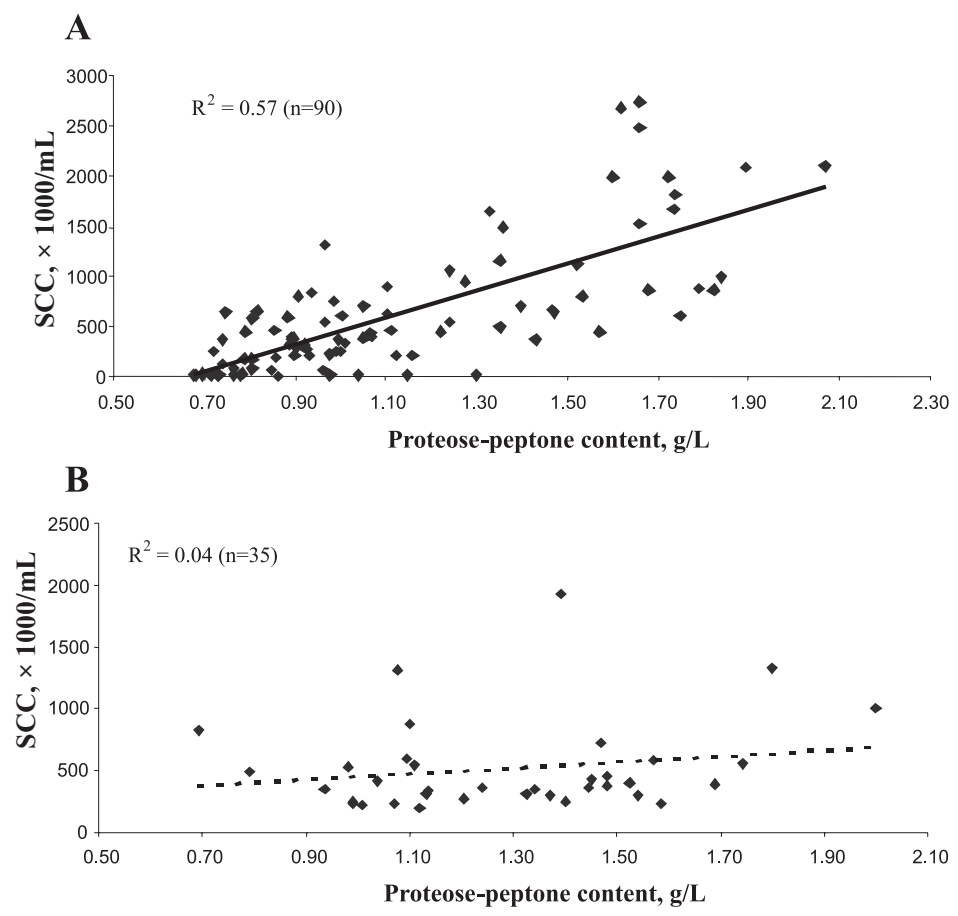

Figure 6. Correlation between SCC and PPC during early phase of infection, (A: day 0 to day 7 , $\mathrm{n}=90 ; \mathrm{P}<0.01$ for $\mathrm{r}>0.26$ ) and during chronic phase of infection ( $\mathrm{B}$ : day 9.5 to day $28, \mathrm{n}=35 ; \mathrm{P}<0.01$ for $r>0.40$ )

produced in the infected tissues and the udder host innate immune responses are equally important. This immune response, which appears to be similar for E. coli and $S$. aureus for the early phase of infection characterized by acute inflammatory and neutrophil migration as the major elements of natural defense differ in the chronic phase. For germs that induce a chronic phase of infection (between 7 and 28 days PI), a high correlation between SCC and proteolysis cannot thus far, be established.

\section{CONCLUSIONS}

This work demonstrated that proteolysis in subclinical mastitis induced by $S$. aureus is a significant event that occurs throughout the duration of the infection cycle. In addition to this finding, it has been established that proteolysis is strongly linked with SCC during the early phase of infection despite the occurrence of minor fluctuations between the parameters which was also observed but considered 
to be insignificant. In contrast to this observation, the correlation between these two parameters during the chronic phase, was relatively weak. For some samples tested, a high SCC (over $10^{6}$ cells $/ \mathrm{mL}$ in a quarter milk) did not correlate with high proteolysis in milk.

In view of the experimental conditions used for the purpose of this study (quarter milk, subclinical mastitis caused by $S$. aureus, chronic phase of infection up to 28 days PI), measurement of SCC did not prove to be a reliable indicator of milk proteolysis. These results herein demonstrated that the increase in SCC levels used primarily as a risk indicator of milk proteolysis, did not consistently correlate with increased proteolysis of milk as predicted. In view of these results, a deeper understanding of the processes involved in the interaction between cytokines and PMN or lymphocytes proteolytic activities would serve as a better path to improve and develop strategies to predict proteolysis in milk during subclinical mastitis.

\section{REFERENCES}

Andrews A.T., Alichanidis E., 1983. Proteolysis of caseins and the proteose-peptone fraction of bovine milk. J. Dairy Res. 50, 275-290

Bank U., Ansorge S., 2001. More than destructive: neutrophil-derived serine proteases in cytokine bioactivity control. J. Leukocyte Biol. 69, 197-206

Bannerman D.D., Paape M.J., Chockalingam A., 2006. Staphylococcus aureus intramammary infection elicits increased production of transforming growth factor- $\alpha, \beta 1$ and $\beta 2$. Vet. Immunol. Immunopathol. 112, 309-315

Bannerman D.D., Paape M.J., Lee J.W., Zaho X., Hope J.C., Rainard P., 2004. Escherichia coli and Staphylococcus aureus elicit differential innate immune responses following intramammary infection. Clin. Diagn. Lab. Immunol. 11, 463-472

Collin J.C., Kokelaar A., Rollet-Repecaud O., Delacroix-Buchet A., 1991. Dosage des caséines du lait de vache par électrophorèse et par chromatographie liquide rapide d'échange d'ions (FPLC): comparaison des résultats. Lait 7, 339-350

Coulon J.B., Gasqui P., Barnouin J., Ollier A., Pradel P., Pomies D., 2002. Effect of mastitis and related-germ on milk yield and composition during naturally-occuring udder infections in dairy cows. Anim. Res. 51, 383-393

De Rham O., Andrews A.T., 1982. Qualitative and quantitative determination of proteolysis in mastitic milk. J. Dairy Res. 49, 587-596

Grönlund U., Johannisson A., Persson Waller K., 2006. Changes in blood and milk lymphocyte subpopulation during acute and chronic phase of Staphylococcus aureus induced bovine mastitis. Ret. Vet. Sci. 80, 147-154

Haddadi K., Prin-Mathieu C., Moussaoui F., Faure G.C., Vangroenweghe F., Burvenich C., Le Roux Y., 2006. Polymorphonuclear neutrophils and Escherichia coli proteases involved in proteolysis of casein during experimental Escherichia coli mastitis. Int. Dairy J. 16, 639-647

Harmon R.J., Eberhardt R.J., Jasper D.E., Langlois B.E., Wilson R.A., 1990. Microbiological Procedures for the Diagnosis of Bovine Udder Infection. National Mastitis Council. Arlington, VA

Harwalkar V.R., Cholette H., Mc Kellar R.C., Emmons D.B., 1993. Relation between proteolysis and astringent off-flavor in milk. J. Dairy Sci. 76, 2521-2527 
Karlsson A., Arvidson S., 2002. Variation in extracellular protease production among clinical isolates of Staphylococcus aureus due to different levels of expression of the protease receptor sarA. Infect. Immunol. 70, 4239-4246

Kelly A.L., O'Flaherty F., Fox P.F., 2006. Indigenous proteolytic enzyme in milk: a brief overview of the present state of knowledge. Int. Dairy J. 16, 563-572

Larsen L.B., Rasmussen M.D., Bjerring M., Nielsen J.H., 2004. Proteases and protein degradation in milk from cows infected with Streptococcus uberis. Int. Dairy J. 14, 899-907

Le Roux Y., Colin O., Laurent F., 1995. Proteolysis in samples of quarter milk with varying somatic cell count. 1. Comparison of some indicators of endogenous proteolysis in milk. J. Dairy Sci. $78,1289-1297$

Leitner G., Krifucks O., Merin U., Lavi Y., Silanikove N., 2006. Interactions between bacteria type, proteolysis of casein and physico-chemical properties of bovine milk. Int. Dairy J. 16, 648-654

Miranda G., Gripon J.C., 1986. Origine, nature et incidences technologiques de la protéolyse dans le lait. Lait $66,1-18$

Moussaoui F., Laurent F., Girardet J.M., Humbert G., Gaillard J.L., Le Roux Y., 2003. Characterization and proteolytic origins of specific peptides appearing during lipopolysaccharide experimental mastitis. J. Dairy Sci. 86, 1163-1170

Moussaoui F., Vangroenweghe F., Haddadi K., Le Roux Y., Laurent F., Duchateau L., Burvenich C., 2004. Proteolysis in milk during experimental Escherichia coli mastitis. J. Dairy Sci. 87. 2923-2931

Nielen M., Schukken Y.H., Brand A., 1995. Detection of subclinical mastitis from on-line milking parlor data. J. Dairy Sci. 78, 1039-1049

Opdenakker G., Van den Steen P.E., Van Damme J., 2001. Gelatinase B: a tuner and amplifier of immune functions. Trends Immunol. 22, 571-579

Rainard P., Riollet C., 2003. Mobilization of neutrophils and defense of the bovine mammary gland. Reprod. Nutr. Develop. 43, 439-457

Riollet C., Rainard P., Poutrel B., 2000. Differential induction of complement fragment C5a and inflammatory cytokines during intramammary infections with Escherichia coli and Staphylococcus aureus. Clin. Diagn. Lab. Immunol. 7, 161-167

Shaw L., Golonka E., Potempa J., Foster S.J., 2005. The role and regulation of the extracellular proteases of Staphylococcus aureus. Microbiology 150, 217-228 